\title{
Proximate Composition and Profiles of Amino Acids and Fatty Acids in the Muscle of Adult Males and Females of Commercially Viable Prawn Species Macrobrachium rosenbergii Collected from Natural Culture Environments
}

\author{
P. Saravana Bhavan \\ Department of Zoology, Bharathiar University, Coimbatore - 641046, Tamilnadu, India
}

Tel: 91-422-242-2222 Ext. 495 E-mail: bhavanps@yahoo.co.in

S. Radhakrishnan

Department of Zoology, Bharathiar University, Coimbatore - 641046, Tamilnadu, India

E-mail: radhas001@yahoo.com

C. Seenivasan

Department of Zoology, Bharathiar University, Coimbatore - 641046, Tamilnadu, India

E-mail: crustaceanseenu@yahoo.com

R. Shanthi

Department of Zoology, Bharathiar University, Coimbatore - 641046, Tamilnadu, India E-mail: cool.shanthi83@rediffmail.com

R. Poongodi

Department of Zoology, Bharathiar University, Coimbatore - 641046, Tamilnadu, India

E-mail: poocrustacean@gmail.com

S. Kannan

Department of Zoology, Bharathiar University, Coimbatore - 641046, Tamilnadu, India

E-mail: skanmbt2000@yahoo.com

\begin{abstract}
The proximate composition of biochemical constituents was analyzed in the muscle of adult male and female prawns of Macrobrachium rosenbergii collected from two different natural culture sites. This was in the order of moisture $>$ protein $>$ amino acids $>$ carbohydrate $>$ nucleic acids $($ RNA $>$ DNA) $>$ lipid $>$ fatty acids $>$ ash. The prawns collected from both natural culture sites showed reasonably good proximate composition. This indicates that the wild has provided adequate food source to the prawns. The proportion of total protein, amino acids, lipid, fatty acids, carbohydrate and RNA were found to be higher in female prawns than in the males. In contrast, the proportions of moisture and ash contents were higher in male prawns when compared with females. The level of DNA was found to be unchanged in both male and female prawns. HPTLC analysis of amino acids revealed higher levels of essential amino acids, such as phenylalanine, leucine, tyrosine, isoleucine, tryptophan, methionine, valine, threonine, arginine, histidine, lysine in female prawns when compared to the male prawns. Similarly, GC analysis of fatty acids showed both polyunsaturated and saturated fatty acids levels were found to be higher in female prawns when compared to the males. The variation in muscle constituents between male and female prawn reflects the differences in sex development and their energy requirements for body maintenance during the adult stage. In the present study, nutrition wise, the adult female prawn was as good or better
\end{abstract}


compared to the adult male prawn. Since $M$. rosenbergii are a good source of protein, essential amino acids and polyunsaturated fatty acids, and very low in fat, it can be used as a healthy choice of food for human consumption.

Keywords: Prawn, Macrobrachium rosenbergii, Proximate composition, Amino acids, Fatty acids

\section{Introduction}

Aquaculture has been described as an underwater agriculture mainly to increase the production above the natural, wild level. It implies some form of intervention in the rearing process by exploiting water bodies to enhance production through regulated stocking density, feeding, and protection from predators etc. The intervention promises the development of sustainable and viable, eco-friendly systems that enable successful commercialization of aquaculture starting from seed production to ensuring supply of quality sea food to the consumer. World aquaculture continues to grow more rapidly than all other animal food-producing sectors, with an average annual growth rate of $8.8 \%$ from a production of below one million Tones in early 1950's to 59.4 million Tones during 2002-2004, with a value of 70.3 billion US \$. During this period, production in developing countries other than China increased at an annual rate of $11.0 \%$, compared with $5.0 \%$ for China alone, and about $2.0 \%$ in the developed countries (FAO, 2007). In freshwater aquaculture, apart from carp, some of the largest growing prawn species of Macrobrachium genera, particularly M. rosenbergii, commonly called 'Scampi' has been found to be more suitable for culture. This species of prawn have remarkable advantage, because of its omnivorous feeding habit, fairly high growth rate, attractive size, better meat quality with good amount of protein, tolerance of wide range of temperature $\left(15-35^{\circ} \mathrm{C}\right)$ and resistance to diseases (Ling, 1969). It has a high market price and a good export potential. It is a nutritious delicacy for mankind.

In India, after the decline of Penaeus culture due to disease problems and serious environmental issues, the fisheries and aquaculture of freshwater prawns came into forefront. The giant freshwater prawn, $M$. rosenbergii inhabits the tidal rivers along the west coast (from Indus delta to Malabar) and east coast (from the south to Mahanathi delta and also deltaic Bengal). Until recently freshwater prawn farming has been practiced by adopting traditional methods, where the young ones collected from the wild were reared in semi intensive farms. Now, artificial seed production technique for successful rearing of larval stages of $M$. rosenbergii is available. This species also shows compatibility for poly culture with carps (Sivashankar, 1995; Mukhopadhyay et al. 1997; Karplus et al. 2000). Species growing to more than $15 \mathrm{~g}$ are suggested as commercially important (Chandrasekaran and Sharma, 1997; Mariappan et al. 2003). M. rosenbergii grows to about $32.0 \mathrm{~cm}$ in length and weighs about $200 \mathrm{~g}$. This has become the favorite species for small-scale as well as large-scale inland aquaculture farming all over the world (Nandlal and Pickering, 2005). Farming of M. rosenbergii in cages in lakes is a viable alternative to pond culture, and has the potential to improve aquaculture production (Cuvin-Aralar et al. 2007).

There are several reports available with respect to improvement of nutritional quality of $M$. rosenbergii under culture conditions (Hilton et al. 1984; Ravishankar and Keshavnath, 1986; Briggs et al. 1988; Reed and D'Abramo, 1989; Sheen and D'Abramo, 1991; Das et al. 1996; Tidewell et al. 1997; Cheng and Hardy, 2004; Hossain et al. 2006; Hossain and Paul, 2007; Hasanuzzaman et al. 2009). However, literature is scanty regarding the proximate composition of $M$. rosenbergii in the wild except a few reports (Cavilli et al. 2001; Thompson et al. 2004; Bhavan et al. 2008). Therefore, in the present study, an attempt has been made to evaluate the proximate composition of basic biochemical constituents, such as total protein, amino acids, carbohydrate, lipid, fatty acids, DNA, RNA, moisture and ash in the muscle of adult male and female $M$. rosenbergii collected from two different natural culture environments. The profiles of amino acids and fatty acids have also been analyzed to assess and differentiate their nutritional quality.

\section{Materials and Methods}

Healthy adult prawns of M. rosenbergii were captured from two natural culture environments, Valayar irrigation canal (site-1) and Malampuzha Reservoir (site-2), Palakkad, Kerala. The male and female prawns were segregated. Ten prawns of almost equal size in each sex were segregated from the capture of each culture site. The matured males are larger than the females and possess enlarged second pair of walking legs. The adults are identified by the enlarged and sharply up turned rostrum and horizontal lines on the carapace, which increase in number with the increasing size of the prawn. In sexually ripened female the fully developed ovary is an orange colored mass and seen through the carapace. They were safely brought to the laboratory in well-oxygenated containers and the morphometric data were taken immediately. 


\subsection{Estimation of Proximate composition}

The prawns were sacrificed and muscle tissues were sampled. The samples were immediately processed for analyzing the proximate composition, such as moisture, protein, amino acids, carbohydrate, nucleic acids (RNA and DNA), lipid, fatty acids and ash, and also for analyzing the profiles of amino acids and fatty acids. The content of total protein was estimated following the method of Lowry et al. (1951) using alcoholic precipitated sample. Total carbohydrate was estimated by the method of Roe (1955) using TCA extracted sample. Total lipid was extract with chloroform-methanol mixture following the method of Barnes and Black-Stock (1973) and estimated by the method of Folch et al. (1957). Amino acids were extracted using Sodium tungstate and $\mathrm{H}_{2} \mathrm{SO}_{4}$. The content of total amino acid was assayed by the method of Moore and Stein (1948). The concentration of fatty acid was estimated by the method of Duncombe (1963). Nucleic acid was extracted from methanol insoluble tissue residue by the method of Schneider (1957), and the contents of DNA and RNA were assayed following the method of Burton (1956) and Ceriotti (1955) respectively. The pre weighed wet tissue samples were dried under $40^{\circ} \mathrm{C}$ to measure the moisture content. The dried tissue sample was subjected to $600^{\circ} \mathrm{C}$ under a Muffle Furnas to measure the ash content.

\subsection{Analysis of the profiles of amino acids}

The profile of amino acids was done following high performance thin layer chromatographic (HPTLC) method (Hess \& Sherma, 2004). The HPTLC profile of amino acids in the muscle of the prawns was analyzed. The prawns were dried $\left(80^{\circ} \mathrm{C}\right.$ for $\left.3 \mathrm{hrs}\right)$, digested with $6 \mathrm{M}$ aqueous hydrochloric acid and dried under vacuum. The powdered sample was dissolved in distilled water and $5 \mu$ of sample was loaded on $8 \mathrm{~mm}$ thick pre-coated Silica gel $60 \mathrm{~F}_{254}$ TLC plate $(20 \mathrm{~cm} \times 15 \mathrm{~cm})$ and processed in CAMAG-LINOMAT 5 instrument. The plate was developed in butane-Ammonia-Pyridine-Water (3.9:1:3.4:2.6) mobile phase. The plate was sprayed with ninhydrin reagent prepared in propan-2-ol and dried. The developed plate was documented using photo-documentation chamber (CAMAG-REPROSTAR 3) at UV $254 \mathrm{~nm}$ and UV366 nm lights. Finally, the plate was scanned at $500 \mathrm{~nm}$ using CAMAG-TLC SCANNER 3. The peak area of the sample was compared with standard amino-acids and quantified.

\subsection{Analysis of the profiles of fatty acids}

The profile of fatty acids was done following gas chromatographic (GC) method (Nichols et al. 1995). Fatty acids were obtained from lipids by saponification using $\mathrm{NaOH}$ dissolved in methanol $\mathrm{H}_{2} \mathrm{O}$ mixture (hydrolysis with alkali). They were methylated into fatty acid methyl ester using $\mathrm{HCl}$ and methanol mixture, which can be easily identified by gas chromatography. The fatty acid methyl ester was separated using mixture of hexane and anhydrous diethyl ether. For the organic phase aqueous $\mathrm{NaOH}$ was used as base wash and the upper organic layer was separated. Two $\mu$ l of sample was injected and analyzed using Chemito 8610 Gas chromatography, with BPX70 capillary column and flame ionization detector. Nitrogen was used as carrier gas. The chromatogram was used for calculation. Standard fatty acids were analyzed simultaneously. Based on the retention time and peak area of the standard fatty acids, each fatty acid in the unknown sample was identified. The recorded data were subjected to statistical analysis by adopting Student ' $t$ ' test (Zar, 1984).

\section{Results}

\subsection{Morphometric variation and proximate composition}

Table 1 depicts morphometric data taken from male and female prawns captured in two different natural culture sites. Prawns collected from site-2 showed higher average body length and mass when compared with prawns of site-1 (Table 1). The differences in body length and mass between culture sites of individual sex, and the differences between sexes of same site were found to be statistically significant except the body length of females between sites. The better market quality was further evident from the higher proximate compositions recorded in prawns captured from culture site-2 (Table 2). Generally, the proximate composition of biochemical constituents recorded was in the order of moisture $>$ protein $>$ amino acids $>$ carbohydrate $>$ nucleic acids (RNA $>$ DNA) $>$ lipid $>$ fatty acids $>$ ash. The proportion of total protein, amino acids, lipid, fatty acids, carbohydrate and RNA were found to be higher in female prawns than in males. The differences recorded in these parameters between sites of the same sex except amino acid were found to be statistically significant. In contrast, the proportions of moisture and ash contents were higher in male prawns than in females. However, the differences in these parameters between sites of the same sex and between sexes of the same site were found to be statistically not significant. The level of DNA was found to be unchanged in the muscle tissue of both male and female prawns (Table 2). 


\subsection{Profiles of amino acids}

The profiles of amino acids detected through HPTLC analyses from the muscle of the prawns are presented in Table 3. Eighteen amino acids were detected, among these phenylalanine, leucine, tyrosine, isoleucine, tryptophan, methionine, valine, threonine, arginine, histidine, lysine are essential amino acids, and, alanine, cysteine, proline, glutamic acid, serine, aspartic acid, glutamine and glycine are non-essential amino acids. The content of these amino acids was found to be higher in prawns collected from culture site-2, when compared to that of site-1. In the case of males the differences recorded particularly for essential amino acids, such as phenylalanine, leucine, valine and arginine were found to be statistically significant. In the case of females the differences recorded for all the essential amino acids except tyrosine and isoleucine, tryptophan, and histidine were found to be statistically significant. Moreover, the female prawns showed more differences in the contents of these amino acids when compared the male prawns (Table 3). The differences between males and females of site-1, in almost all the essential amino acids were found to be statistically significant. However, in the case of site-2, in addition to essential amino acids, the differences recorded in non-essential amino acids as well were found to be statistically significant.

\subsection{Profiles of fatty acids}

The profiles of fatty acids detected through GC analyses from the muscle of the prawns are presented in Table 4. There were 15 fatty acids detected, which include both essential (unsaturated) and saturated fatty acids. The essential fatty acids (EFA), mono and polyunsaturated fatty acids cannot be synthesized by the body. The n-3 $(\omega-3)$ series of polyunsaturated fatty acids detected in the muscle of prawns was linoleic acid (18:2), eicosapentaenoic acid (EPA) (20:5), docosahexaenoic acid (DHA) (22:5) and octadecatatrienoic acid (18:4). Similarly, the n-6 ( $\omega-6)$ series of polyunsaturated fatty acids detected was linolenic acid (18:3) and arachidonic acid (20:4). The mono unsaturated fatty acids detected were palmitoleic acid (16:1), oleic acid (16:1), docosanic acid (22:1) and erucic acid (22:1). The others were saturated fatty acids, such as myristic acid (14:0), palmitic acid (16:0), stearic acid (18:0), arachidic acid (20:0) and lignoceric acid (24:0) (Table 4). The contents of fatty acids, especially the essential fatty acids, were found to be higher in both male and female prawns collected from culture site-2, when compared to that of site-1. In males, the differences recorded particularly for essential fatty acids, such as linolenic acid, EPA, DHA, octadecatatrienoic acid, docosanic acid, erucic acid and arachidonic acid were found to be statistically significant. In females, the differences recorded for linolenic acid, EPA, DHA, octadecatatrienoic acid and erucic acid only were found to be statistically significant (Table 4). Moreover, when the differences in the fatty acids contents recorded between male and female were compared, it was found that all the essential fatty acids were found to be statistically significant in both site- 1 and site-2 (Table 4).

\section{Discussion}

Edible crustaceans, such as crab, shrimp, prawn, crayfish and lobster constitute one of the major sources of nutritious food for human being. Among seafood, prawns and shrimps contribute about $20 \%$ by volume of the world seafood market. Seafood in general, and prawns and shrimps in particular, are highly nutritious with good source of protein and amino acids. The fiber in prawns has a nutritional advantage in that it will assist in reducing constipation and other attendant problems in human consumers. The nutritive values of crustaceans depend upon their biochemical composition, such as protein, amino acids, lipid, fatty acids, carbohydrate, vitamins and minerals. In the present study, the observed results in the proximate composition, and profiles of amino acids and fatty acids in adult male and female prawn, $M$. rosenbergii reared under natural environment have been compared and discussed from a nutritional point of view.

\subsection{Morphometry}

In aquaculture, the length-weight data provide some useful information in market oriented farm management (Cheng and Chen, 1990; Primavera et al. 1998; Chow and Sandifer, 199; Peixoto et al. 2004). In the present study, the collected prawns were of a marketable size and such sized prawns fetched up to Rs.500 per kg in the local market depending upon the demand. It has been reported that the growth rate of $M$. rosenbergii depends upon age and sex, genetic influences of parent type, rate and frequency of feeding, quality of food, disease, and environmental factors, such as stocking density, temperature, oxygen tension and water quality in terms of waste products (New et al. 2008). These factors also influence the duration of the intermolt period and the molt size increment. These two interlinked aspects determine the growth rates, with faster growth rates at higher food concentrations and higher temperature (Hartnoll, 1983). In freshwater crustaceans, differences between the relative growth of chelipeds and abdomen usually coincide with sexual maturation (Holdich and Lowey 1988). It has been reported that in males, there was a dramatic increase in the relative size of the chelae and chelipeds, while females increase the relative size of the abdomen (Gu et al. 1994). In the present study, the body mass 
means, total weight of the animal including chelate legs. The difference in body mass between male and female prawns was much higher when compared to the difference recorded in body length (Table 1). Usually, the matured males are larger than the females and possess enlarged second pair of walking legs. Therefore, chelate legs contribute much in total body mass of male prawns.

\subsection{Proximate composition}

Prawns contain good amount of organic and inorganic constituents. The main constituents are protein, amino acid, carbohydrate and lipid. In addition to that prawns also contain a significant proportion of minerals $(\mathrm{Ca}, \mathrm{P}$, $\mathrm{Mg}, \mathrm{Mn}$ and $\mathrm{Cl}$ ) and vitamins (A, C and D) (Abulude, et al., 2006). The proximate body composition including moisture, fat, protein and ash are good indicators of physiological condition of an organism. The greater the protein and lipid content represents higher the energy density (Dempson, et al. 2004). However, quantities of these constituents vary considerably within and between species, size, sexual condition, feeding season and physical activity (Rosa and Nunes, 2003; Nargis, 2006). In this investigation, the proportion of protein was greater followed by carbohydrate and lipid in the muscle of the prawns. Moreover, the concentration of protein was found to be significantly higher in the female prawns when compared to the male prawns (Table 2). Similar difference between male and female sex has been reported in fish, and furthermore, the protein components of muscle tissues varied with the change of season, and the seasonal variation found in females was greater than in the males (Nargis, 2006).

\subsubsection{Protein and amino acids}

One of the major requirements of prawn culture is the transformation of dietary protein into tissue protein. Protein is essential for normal function, growth and maintenance of body tissues. Its content is considered to be an important tool for the evaluation of physiological standards (Diana, 1982). Amino acids are the building blocks of proteins and serve as body builders. They are utilized to form various cell structures, of which they are key components and they serve as source of energy (Babsky et al. 1989). Crustacean muscles contain high concentration of free amino acids, such as arginine, glycine, proline, glutamine and alanine (Cobb et al. 1975). The free amino acids have been shown to function in osmoregulation (Fang et al, 1992). They have major contribution to the flavor of sea food (Thompson et al. 1980). The amino acid, tryptophan plays an important role in the brain as a precursor of the neurotransmitter, serotonin, which has a major effect on the feeding behavior of animals (Mullen and Mortin, 1992). Valine is involved in many metabolic pathways and is considered indispensable for protein synthesis and optimal growth (Wilson, 2002). Histidine is also an indispensable amino acid involved in many metabolic functions including the production of histamines, which take part in allergic and inflammatory reactions. It plays a very important role in maintaining the osmoregulatory process and is related to energy production or is used in other metabolic pathways during certain emergencies/ harsh conditions (Abe and Ohmama, 1987). In the present study, the levels of indispensable amino acids were found to be increased in female prawns in comparison to the male prawns. This suggests sex differences and unique physiology of adult female prawns. The overall contents of these amino acids indicate that the growth of both male and female prawns was progressed positively in the wild.

\subsubsection{Carbohydrate}

Carbohydrates are considered to be the first among the organic nutrients to be utilized to generate required energy (Heath, 1987). They serve as precursors for the dispensable amino acids and some nutrients, which are metabolic intermediates necessary for growth (NRC, 1993). They exist both in free and in bound state along with proteins as protein-bound sugars and glycogen. The concentration of carbohydrate in the muscle showed some differences when compared between male and female prawns, as well as prawns of the same sex of different culture sites (Table 2). This indicates the availability of such an important and immediate energy precursor in the wild for the survival and growth of $M$. rosenbergii.

\subsubsection{Lipid and fatty acids}

Lipids are extremely important in maintaining structural and physiological integrity of cellular and sub- cellular membranes. Lipids are the best source of energy producers of the body through metabolism. They provides a source of indispensable nutrients and act as carriers of certain non fat nutrients, notably the fat soluble vitamins like A, D, E and K (New, 1986; Richardo et al. 2003). In the present study, the level of total lipid was found to higher in female prawns when compared to the male prawns (Table 2). Moreover, the levels of polyunsaturated fatty acids (PUFA), such as linoleic, linolenic, eicosapentaenoic (EPA), decosapentaenoic (DHA), octadecatatraenoic and arachidonic acids were found to be higher in female prawns when compared with male prawns (Table 4). The hepatopancreas is the main lipid storage organ, triglycerides and phospholipids being its major lipid components, while the muscle contained mainly phospholipids (Muriana et al. 1993; Chanmugam et al. 2006). 
Generally, the muscle of the prawn contained lower quantity of lipid (Bhavan et al. 2008; Bhavan, 2009). Therefore, prawns and other sea foods are preferred by the consumer. Lipids also form a major component of yolk in decapod crustaceans. The majority of lipids stored in oocytes are derived from extraneous sources, particularly the hepatopancreas (Varadarajan and Subramoniam, 1982). Lipids are the precursors of endocrine hormones. The higher quantity of total lipid and fatty acids recorded in the adult female prawns may be necessitated for performing certain specific physiological activity related to reproduction.

It has been reported that incorporation of essential fatty acids in the diet produced better growth rate and survival in aquaculture (Read, 1981; Sargent et al. 1999; Bell and Sargent, 2003). In the present study, the presence of n-3 PUFA, particularly, linoleic, EPA and DHA indicates better growth and survival of M. rosenbergii in the wild. The higher levels of EPA and DHA would increase stress tolerance and membrane permeability (Watanabe et al. 1989; Watanabe, 1993). The arachidonic acid (n-6) is a precursor of prostaglandin hormone, which is essential for reproduction and vitellogenesis (Bell and Sargent, 2003; Tamaru et al. 1997, Tamaru and Ako, 2000). In the present study, the presence of higher level of arachidonic acid in the adult female prawns when compared to that of male prawns indicates its physiological state. The level of oleic acid (n-9) was also recorded to be comparatively higher in female prawns than in male prawns. In the present investigation, both sexes of $M$. rosenbergii contained high levels of EFA. However, the fact that female prawns had greater quantity of these fatty acids than the male prawns indicates their nutritional value, physiological and reproductive states.

The interaction and balance between $\omega-3, \omega-6$ and $\omega-9$ fatty acids are crucial for maintenance of good health (Christensen et al. 2001; Von-Schacky et al. 1999). The $\omega-3$ fatty acids have anti-inflammatory and anti-coagulant properties as well as many other important health benefits. The DHA is important for pregnant and nursing mothers and in young children for healthy development of the brain and vision. The EPA can be considered the most important for everyone else as it is necessary for continuation of the efficient functioning of the brain and body at the cellular level. The $\omega-6$ fatty acids have their own role in female reproductive cycle. The $\omega-9$ fatty acids help to reduce the risk of arteriosclerosis, cardiovascular disease and stroke. Since M. rosenbergii contains considerable amounts of PUFA it can provide a healthy choice of daily diet.

\subsubsection{Nucleic acids}

Crustaceans change physiologically throughout the molt cycle and exhibit pronounced biochemical changes associated with specific molt stages (Moss, 1994). In the present investigation, the concentration of DNA was found to be almost equal in both male and female prawns (Table 2). It has also been reported that the DNA content remained remarkably stable and assumed to be constant in normal somatic cells of Penaeus monodon (Kian and Mustafa, 2005). The quantity of RNA within a cell is highly variable and reflects the activity of protein synthesis (Khan and Jafri, 1991; Tripathi and Verma, 2003). In the present study, the concentration of RNA was found to be slightly higher in female prawns when compared with male prawns (Table 2). This suggests that the adult female prawns were in synthetic stage. To support this fact, the increased RNA content in the hepatopancreas and muscle of Penaeus indicus has been correlated with enhanced protein synthesis and better growth (Jayaprakas and Sambhu (1996). The higher level of protein and RNA, and unchanged DNA has also been reported in the crayfish, Orconectes virilis during the normal pre molt stage (Gorell and Gilbert, 2004).

\subsubsection{Moisture and ash}

Prawns and shrimps are highly perishable because of their high moisture content, low connective tissue and their high amino acid content (Shamasunder and Prakash, 1994). In the present study, the contents of moisture and ash were found to be slightly higher in male prawns than that of the female prawns. It has been reported that the muscle of male prawns contained higher levels of ash and water, and the females have relatively greater amounts of fat, protein and carbohydrates (Amer et al. 1991). It has also been reported in fish that the moisture content in the case of male was higher when compared to that of female both in winter and summer seasons (Nargis, 2006). The proximate composition observed in the present study suggests that the mineral constituents were higher in male prawns when compared to those of female prawns. The high moisture content of males explains their higher body mass compared to females.

The dynamics of protein, lipid, carbohydrate, and other important biochemical components involved in energy metabolism were regulated by various factors, such as sex, reproductive cycle, capture period, food availability, hydrologic level etc. (Tzeng et al. 2001; Oliveira et al. 2003; May-Ku et al. 2006; Nargis, 2006). In the present study, the variation in muscle constituents between male and female prawn reflects the differences in sexual development and their energy requirements for maintenance of body physiology during the adult stage. Therefore, the recorded data indicate that sex has a role in growth rate and meat quality of $M$. rosenbergii.

In conclusion, the prawns collected from both culture sites showed reasonably good proximate composition. This 
indicates that wilderness has provided the required nutrients to the prawns. As the water bodies in the wild were not controlled and maintained like a confined culture pond, they should have contained all types of food items. The various food items should have been consumed, since this species of prawn is omnivorous in behavior. However, the prawns of culture site- 2 showed better proximate composition than the prawns taken from culture site-1. This may because of the physical, chemical and biological conditions related to the habitat. The recorded data indicates that nutritionally the adult female prawns were good or even better than the adult male prawns. Since $M$. rosenbergii is a good protein source and low in fat with lots of essential amino acids and polyunsaturated fatty acids this species of prawn can be recommended as a healthy choice for human consumption.

\section{References}

Abe, H., \& Ohmama, S. (1987). Effect of starvation, and seawater acclimation on the concentration and free L-histidine and related dipeptides in the muscle of eel, rainbow trout and Japanese dace. Comp. Biochem. Physiol, 88B, 507-511.

Abulude, F.O., Lawal, L.O., Ehikhamen, G., Adesanya, W.O., \& Ashafa, S.L. (2006). Chemical composition and functional properties of some prawns from the coastal area of Ondo state, Nigeria. Electron. J. Environ. Agric. Food Chem., 5, 1235-1240.

Amer., H.A., Sedik, M.F., Khalafalla, F.A., \& Abd E1-Ghany Awad, H. (1991). Results of chemical analysis of prawn muscle as influenced by sex variations. Molecular Nutrition and Food Research, 35, 133-138.

Babsky, E.B., Khodorov, B.I., Kositsky, G.I., \& Zubkov, A.A. (1989). In Babsky, E.B. (Ed.), Human Physiology, Mir Publishers, Moscow.

Barnes, H., \& Blackstock, J. (1973). Estimation of lipids in marine animals and tissues. Detail investigation of the sulpho-phosphovanillin method for total lipids. J. Expl. Mar. Ecol., 12, 103-118.

Bell, J.G., \& Sargent, J.R. (2003). Arachidonic acid in aquaculture feeds: current status and future opportunities. Aquaculture, 218, 491-499.

Bhavan, P.S., Yuvaraj, C., Leena, M., \& Sangeetha, M. (2008). Concentrations of total protein, lipid, and carbohydrate in juveniles and sub adults of the prawn Macrobrachium malcolmsonii collected from the Cauvery River. Indian J. Fisheries, 55, 323-325.

Bhavan, P.S. (2009). Concentrations of total protein, lipid, carbohydrate, DNA and ATPase in tissues of the freshwater prawn Macrobrachium malcolmsonii. Fishing Chimes, 29, 44-46.

Briggs, M.R.P., Jauncey, K., \& Brown, J.H. (1988). The cholesterol and lecithin requirements of juvenile prawn (Macrobrachium rosenbergii) fed semi purified diets. Aquaculture, 70, 121-129.

Burton, K. (1956). A study of the condition and mechanism of the diphenylamine for the colorimetric estimation of deoxyribonucleic acid. Biochem J., 62, 315-323.

Cavalli, R.O., Tamtin, M., Lavens, P., \& Sorgeloos, P. (2001). Variation in lipid classes and fatty acid content in tissues of wild Macrobrachium rosenbergii (de man) females during maturation. Aquaculture, 193, 311-324.

Ceriotti, G. (1955). Determination of nucleic acid in animal tissues. J. Biol. Chem., 214, 59-70.

Chandrasekaran, V.S., \& Sharma, P. (1997). Biology and culture of freshwater prawns in North India. Fishing Chimes, 17, 7-9.

Chanmugam, P., Donovan, J., Wheeler, C.J., \& Hwang, D.H. (2006). Differences in the lipid composition of fresh water prawn (Macrobrachium rosenbergii) and marine shrimp. J. Food Science, 48, 1440-1441.

Cheng, Z.J., \& Hardy, R.W. (2004). Protein and lipid sources affect cholesterol concentrations of juvenile pacific white shrimp, Litopenaeus vannamei (Boone). J. Anim. Sci., 82, 1136-1145.

Cheng, C.S., \& Chen, L. (1990). Growth and relationships among body length and tail weight of Penaeus monodon from culture environment in Taiwan. Aquaculture, 9, 253-263.

Chow, S.N., \& Sandifer, P.A. (1991). Differences in growth, morphometric traits and male sexual maturity among pacific white shrimp, Penaeus vannamei, from different commercial hatcheries. Aquaculture, 92, $165-178$.

Christensen, J.H., Skou, H.A., Fog, L. Hansen, V., Vesterlund, T., Dyerberg, J., \& Toft, E. (2001). Marine n-3 fatty acids, wine intake, and heart sate variability in patients referred for coronary angiography. Circulation, 103, 651-657. 
Cobb, B.F., Conte, F.S., \& Edwards, M.A. (1975). Free amino acids and osmoregulation in penaeid shrimp. $J$. Agric. Food Chem., 23, 1172-1174.

Cuvin-Aralar M.L.A., Aralar, E.V., Laron, M., \& Rosario, M. (2007). Culture of Macrobrachium rosenbergii (de Man 1879) in experimental cages in freshwater eutrophic lake at different stocking densities. Aqua. Res., 38, 288-294.

Das, N.N., Saad, C.R., Ang, K.J., Law, A.T., \& Harmin, S.A. (1996). Diet formulation for Macrobrachium rosenbergii brood stock based on essential amino acid profile of its eggs. Aqua. Res., 27, 543-555.

Dempson, I.B., Schwarz, C.J., Sbears, M., \& Furey, G. (2004). Comparative proximate body composition of Atlantic salmon with emphasis on parr from fluvial and lacustrine habitats. J. Fish Biol., 64, 1257-1271.

Diana, J.S. (1982). An experimental analysis of the metabolic rate and food utilization of northern pike. Comp. Biochem. Toxicol., 59, 989-993.

Duncombe, W.G. (1963). The colorimetric micro determination of long-chain fatty acids. Biochem. J., 88, 7-10.

Fang, L.S., Tang, C.K., Lee, D.L., \& Chen, I.M. (1992). Free amino acid composition in muscle and hemolymph of the prawn Penaeus monodon in different salinities. Nippon Suisan Gakkaishi, 58, 1095-1102.

FAO. (2007). World aquaculture and fisheries statistics. FAO Publication, Rome, Italy.

Folch, J., Lees, M., \& Sloane-stantly, G.H. (1957). A simple method for the isolation and purification of total lipids from animal tissues. J. Biol. Chem., 226, 497-308.

Gorell, T.A., \& Gilbert, L.L. (2004). Protein and RNA synthesis in the pre molt crayfish, Orconectes virilis. J. Comp. Physiol. Neuroethology, Sensory, Neural and Behavioral physiology, 73, 345-356.

Gu, H., Matuer, P.B., \& Capra, M.F. (1994). The relative growth of chelipeds and abdomen and muscle production in male and female red claw crayfish, Cherax quadricarinatus on Martens. Aquaculture, 123, 249-257.

Heath, A.G., (1987). Water pollution and fish physiology. (Chap. 5), Physiological Energetic (pp. 131-163). CRC Press, Boca Raton, FL.

Hartnoll, R.G., (1983). Growth. In D.E. Bliss (Ed.), The Biology of Crustacea (pp. 214-282), Vol. 8, Academic Press, New York.

Hasanuzzaman, A. F. M., Siddiquil, M.N., \& Chisty, M.A.H. (2009). Optimum replacement of fishmeal with soybean meal in diet for Macrobrachium rosenbergii (De Man 1879) cultured in low saline water. Turkish J. Fish. Aqu. Sci., 9, 17-22.

Hess, B., \& Sherma, J. (2004). Quantification of arginine in dietary supplement tablets and capsules by silica gel high-performance thin-layer chromatography with visible mode densitometry. Acta Chromatographica, 14, 60-69.

Hilton J.W., Harrison K.E., \& Slinger, S.J. (1984). A semi-purified test diet for Macrobrachium rosenbergii and the lack of need for supplemental lecithin. Aquaculture, 37, 209-215.

Holdich, D.M., \& Lowey, R.S. (1988). Freshwater Crayfish. In Biology, Management and Exploitation. Croom Helm, London, England.

Hossain M.A., \& Paul, L. (2007). Low-cost diet for monoculture of giant freshwater prawn (Macrobrachium rosenbergii (de Man) in Bangladesh. Aqua. Res., 38, 232-238.

Hossain, M.A., Siddique, M.A.L., \& Miaje, M.A.H. (2006). Development of low-cost feed for culture of giant fresh water prawn Macrobrachium rosenbergii de Man in ponds. Bangladesh J. Fisheries, 4, 127-134.

Jayaprakas, V., \& Sambhu, C. (1996). Growth response of white prawn, Penaeus indicus to dietary L-carnitine. J. Asian Fisheries Science, 9, 209-219.

Karplus, I., Malecha, S.R., \& Sagi, A. (2000). The biology and management of size variation. In M.B. New, \& W.C. Valenti (Eds.), Freshwater Prawn Culture. The Farming of Macrobrachium rosenbergii (pp. 259-289). Blackwell, Blackwell Science.

Khan, M.A., \& Jafri, A.K. (1991). Protein and nucleic acid concentration in the muscle of catfish Clarias batrachus at different dietary protein level. Asian Fisheries Science, 4, 75-84.

Kian, A.Y.S., \& Mustafa, S (2005). Influence of enriched live prey and other artificial diets on RNA and DNA concentration in the ovary of Tiger prawn, Penaeus monodon. J. Appl. Aquacult, 16, 147-153. 
Ling, S.W. (1969). The general biology and development of Macrobrachium rosenbergii (De Man). FAO fish. Report, 57, 607-619.

Lowry, O.H., Rosebrough, N.J., Farr, A.L., \& Randall, R.J. (1951). Protein measurement with Folinphenol Reagent. J. Biol. Chem., 193, 265-276.

Mariappan, P., Balamurugan, P., \& Balasundaram, C. (2003). Freshwater prawn Macrobrachium nobili a promising candidate for rural nutrition. Curr. Sci., 8, 13-14.

May-Ku, M.A., Ordonez-Lopez, U., \& Defeo, O. (2006). Morphometric differentiation in small juveniles of the pink spotted shrimp (Farfantepenaeus brasiliensis) and the southern pink shrimp (F. notialis) in the Yucatan Peninsula, Mexico. Fishery Bulletin, 104, 306-310.

Moore, S., \& Stein, W.H. (1948). Photometric ninhydrin method for use in the chromatography of amino acid. $J$. Biol. Chem., 176, 367-388.

Moss, S.M. (1994). Use of nucleic acids as indicators of growth in juvenile white shrimp, Penaeus vannamei. Marine Biology, 120, 359-367.

Mukhopadhyay, M.K., Bhaumik, A.K.U., Das, A.K., \& Saha, S.K. (1997). Feasibility studies on production of Macrobrachium rosenbergii in low saline wetlands of West Bengal. In Vass, K.K., \& Sinha, M. (Ed.), Proc. Natl. Semi. Changing Perspective. Inland Fisheries, (pp. 150-153), Barrackpore, India.

Mullen, B.J. \& Martin, R.J. (1992). The effect of dietary fat on diet selection may involve central serotonin. Am. J. Physiol. Regul. Integr. Comp. Physiol., 263, R559-R563.

Muriana, F.J.G., Ruiz-Gutierrez, V., Gallardo-Guerrero, M.L., \& Mínguez-Mosquera, M.I. (1993). A study of the lipids and carotene protein in the prawn, Penaeus japonicus. J. Biochem, 114, 223-229.

Nandlal, S., \& Pickering, T. (2005). Freshwater prawn Macrobrachium rosenbergii farming in Pacific Island countries. Hatchery operation. Noumea, New Caledonia. Secretariat of the Pacific Community, 1, 1-15.

Nargis, R. (2006). Seasonal variation in the chemical composition of body flesh of koi fish Anabas testudineus (Block) (Anabantidae, Perciformes). Bangladesh J. Sci. Ind. Res., 41, 219-226.

New, M.B. (1986). Aquaculture diets of post larval marine fish of the super-family Percoidae, with special reference to sea bass, sea breams, groupers and yellow tail: a review. Kuwait bulletin of Marine Science, 7, 75-151.

New, M.B., Nair, C.M., Kutty, M.N., Salin, K.R., \& Nandeesha, M.C. (2008). Macrobrachium. The culture of freshwater prawns. McMillan India Ltd.

Nichols, D.S., Nichols, P.D., \& McMeekin, T.A. (1993). Polyunsaturated fatty acids in Antarctic bacteria. Antarctic Science, 5, 149-160.

NRC (National Research Council. (1993). Nutrient requirements of fish, (p. 114). Committee on Animal Nutrition. Board on Agriculture. National Research Council. National Academy Press. Washington DC, USA.

Oliveira, E.R.N., Agostinho, A.A., \& Matsushita, M. (2003). Effect of biological variables and capture period on the proximate composition and fatty acid composition of the dorsal muscle tissue of Hypothalmus edentatus (Spix, 1829). Brazilian Archives of Biol. Technol., 46, 105-114.

Peixoto, S., Soares, R., Wasielesky, W., Cavalli, R.A., \& Jensen, L. (2004). Morphometric relationship of length and weight of cultured Farfantepenaeus paulensis during nursery, grow out, and brood stock production phases. Aquaculture, 242, 292-299.

Primavera, J.H., Parado-Estepa., \& Lebata, F.D. (1998). Morphometric relationship of length and weight of giant tiger prawn Penaeus monodon according to life stage, sex and source. Aquaculture, 164, 67-75.

Ravishankar, A.N., \& Keshavanath, P. (1986). Growth response of Macrobrachium rosenbergii (de Man) fed on four pelleted feeds. Indian J. Anim. Sci., 56, 110-115.

Read, G.H.L. (1981). The response of Penaeus indicus (Crustacea: Penaeidae) to purified and compound diets of varying fatty acid composition. Aquaculture, 24, 245-256.

Reed, L., \& D'Abramo, L.R. (1989). A standard reference diet for crustacean nutrition research III. Effects on weight gain and amino acid composition of whole body and tail muscle of juvenile prawns Macrobrachium rosenbergii. J. World. Aqua. Soci., 20, 107-113. 
Ricardo, L.S., James, T.L., Zelionara, P.B., Bianchini, A., \& Luiz Eduardo Maia, N.Y. (2003). Lipids as energy source during salinity acclimation in the euryhaline crab Chasmagnathus granulata Dana, 1851 (crustacea -grapsidae). J. Exp. Zool., 295 A, 200-205.

Roe, J.H. (1955). The determination of sugar in blood and spinal fluid with anthrone reagent. J. Biol. Chem., 212, 335-343.

Rosa, R., \& Nunes M.L. (2003). Biochemical composition of deep-sea decapod crustaceans with two different benthic life strategies of the Portuguese south coast. Deep-Sea Res., 50, 119-130.

Sargent, J., McEvoy, L., Estevez, A., Bell, G., Bell, M., Henderson, J., \& Tocher, D. (1999). Lipid nutrition of marine fish during early development: current status and future directions. Aquaculture, 179, 217-229.

Schneider, W.C. (1957). Determination of nucleic acids in tissues by pentose analysis. In S.P. Colowick \& N.O. Kaplan (Eds.), Methods in Enzymology, Vol. III, (p. 680-684). Academic Press, London.

Shamasunder, B.A., \& Prakash, V. (1994). Physicochemical and functional properties of proteins from prawns (Metapenaeus dobsoni). J. Agric. Food Chem., 42, 169-174.

Sheen, S.S., \& D'Abramo, L.R. (1991). Response of juvenile freshwater prawn, Macrobrachium rosenbergii to different levels of cod liver oil/ corn oil mixture in semi purified diet. Aquaculture, 93, 121-134.

Shivashankar, N. (1995). Use of inland saline and alkali soils for freshwater prawn farming in Tungabhadra command area, Karnataka - case- study. In M.E., Dasgupta, D.C. Ghosh, D. Dasgupta, D.E. Majmudar, G.N. Chattopadhyay, P.K. Ganguli, P.S. Munsi, \& D. Battacharya (Eds.), Proc. Natl. Symp. Sustain. Agriculture. Sub littoral Zone, (pp. 268-271), Birbhum, India.

Tamaru, C.S., \& Ako, H. (2000). Using commercial feeds for the culture of freshwater ornamental fishes in Hawaii. In C. Tamaru, C.S. Tamaru, S.P. Mevey, \& K. Ikute (Eds.), Spawning and maturation of aquatic species, UJNR Technical Report No.28, (pp. 109-120). University of Hawaii sea grant college program, Honolulu, Hawaii.

Tamaru, C.S., Ako, H., \& Paguirigan, R. (1997). Fatty acid profiles of maturation feed used in freshwater ornamental fish culture. Hydrobiologia, 358, 265-268.

Thompson, A.B., McGill, A.S., Murray, J., Hardy, R., \& Howgate, P.F. (1980). The analysis of a range of non-volatile constituents of cooked haddock (Gadus aeglefinus) and the influence of these on flavor. In J.J. Connell (Ed.), Advances in Fish Science and Technology, (p. 484). Fishing Books, Farnham, Surrey.

Thompson, K.R., Muzinic, L.A., Yancey, D.H., Webster, C.D., Rouse, D.B., \& Xiong, Y. (2004). Growth, processing measurements, tail meat yield, and tail meat proximate composition of male and female Australian red claw crayfish, Cherax quadricarinatus, stocked into earthen ponds. J. Appl. Aquaculture, 16, 117-129.

Tidewell, J.H., Schulmeister, G. Mahl, C. \& Coyle, S. (1997). Growth, survival and biochemical composition of freshwater prawns Macrobrachium rosenbergii fed natural food organisms under controlled conditions. J. World Aqua. Soc., 28, 123-132.

Tripathi, G., \& Verma, P. (2003). Starvation induced impairment of metabolism in a fresh water catfish. $Z$. Naturforsch, 58C, 446-451.

Tzeng, T., Chiu, C., \& Yeh, S. (2001). Morphometric variation in red-spot prawn (Metapenaeopsis barbata) in different geographic waters of Taiwan. Fish. Res., 53, 211-217.

Varadarajan, S., \& Subramoniam, T. (1982). Biochemical changes during vitellogenesis in a hermit crab, Clibanarius clibanarius. In T. Subramoniam, \& S. Varadarajan, S. (Eds.), Aquaculture proceedings of the first all India symposium on Invertebrate Reproduction (pp. 7-14). New century printers, Madras, India.

VonSchacky, C., Augerer, P., Kothny, W., \& Theisen, N. (1999). The effect of dietary $\omega-3$ fatty acids on coronary arthrosclerosis. Ann. Intern. Med., 130, 554-562.

Watanabe, T. (1993). Importance of docosahexaenoic acid in marine larval fish. J. World Aquac. Soc., 24, 152-161.

Watanabe, T., Arakawa, T., Takeuchi, T., \& Satoh, S. (1989). Comparison between eicosapentaenoic and docosahexaenoic acids in terms of essential fatty acid efficiency in juvenile striped jack Pseudocaranx dentex. Nippon Suisan Gakkasihi, 55, 1989-1995.

Wilson, R.P. (2002). Amino acids and Protein. In J.E. Halver \& R.W. Hardy (Eds.), Fish Nutrition, (pp. 143-179). Academic Press, San Diego. CA, USA.

Zar, J.H. (1984). In E. Kurtz (Ed.), Biostatistical Analysis. ( $3^{\text {rd }}$ ed.). Prentice Hall, Inc., New Jersey. Ricardo. 
Table 1. Morphometric data of adult $M$. rosenbergii collected from two different natural culture sites

\begin{tabular}{|c|c|c|c|c|c|c|c|c|}
\hline \multirow[t]{2}{*}{ Parameters } & \multicolumn{3}{|c|}{ Male } & \multicolumn{3}{|c|}{ Female } & \multicolumn{2}{|c|}{$\begin{array}{c}\text { Difference } \\
\text { Between } \\
\text { Male and Female }\end{array}$} \\
\hline & Site-1 & Site-2 & Difference & Site-1 & Site-2 & Difference & Site-1 & Site-2 \\
\hline $\begin{array}{c}\text { Body Length } \\
\text { (cm) }\end{array}$ & $\begin{array}{c}15.20 \pm \\
2.25\end{array}$ & $\begin{array}{c}18.10 \pm \\
2.20\end{array}$ & $2.9^{*}$ & $\begin{array}{c}9.10 \pm \\
2.30\end{array}$ & $\begin{array}{c}10.20 \pm \\
2.50\end{array}$ & $1.1^{\mathrm{NS}}$ & $6.1^{*}$ & $7.9 *$ \\
\hline Body mass (g) & $\begin{array}{l}125.50 \\
\pm 10.25\end{array}$ & $\begin{array}{l}141.50 \\
\pm 12.50\end{array}$ & $16.0^{*}$ & $\begin{array}{c}35.20 \pm \\
5.20\end{array}$ & $\begin{array}{c}42.45 \pm \\
3.80\end{array}$ & $7.2^{*}$ & $90.3^{*}$ & $99.0^{*}$ \\
\hline
\end{tabular}

Each value is mean \pm SD of 10 individual prawns. *Significant at $1.0 \%$ level $(\mathrm{P}<0.01) .{ }^{\text {NS }}$ Not statistically significant.

Table 2. Proximate composition ( $\mathrm{g} / 100 \mathrm{~g}$ wet wt.) of muscle tissue of adult $M$. rosenbergii collected from two different natural culture sites

\begin{tabular}{|c|c|c|c|c|c|c|c|c|}
\hline \multirow[t]{2}{*}{$\begin{array}{c}\text { Proximate } \\
\text { Composition } \\
\%\end{array}$} & \multicolumn{3}{|c|}{ Male } & \multicolumn{3}{|c|}{ Female } & \multicolumn{2}{|c|}{$\begin{array}{c}\text { Difference } \\
\text { Between } \\
\text { Male and Female }\end{array}$} \\
\hline & Site-1 & Site-2 & Difference & Site-1 & Site-2 & Difference & Site-1 & Site-2 \\
\hline Protein & $\begin{array}{c}24.55 \pm \\
1.25\end{array}$ & $\begin{array}{c}27.25 \pm \\
1.76\end{array}$ & $2.70^{*}$ & $\begin{array}{c}28.56 \pm \\
1.75\end{array}$ & $\begin{array}{c}32.10 \pm \\
1.82\end{array}$ & $3.54 *$ & $4.01^{*}$ & $2.85^{*}$ \\
\hline Carbohydrate & $\begin{array}{c}7.55 \pm \\
1.50\end{array}$ & $\begin{array}{c}10.50 \pm \\
1.70\end{array}$ & $2.95 *$ & $\begin{array}{c}8.40 \pm \\
1.52\end{array}$ & $\begin{array}{c}12.58 \pm \\
1.90\end{array}$ & $4.18^{*}$ & $0.85^{\mathrm{NS}}$ & $2.08^{\mathrm{NS}}$ \\
\hline Lipid & $\begin{array}{c}3.35 \pm \\
0.32\end{array}$ & $\begin{array}{c}5.35 \pm \\
0.35\end{array}$ & $2.00^{*}$ & $\begin{array}{c}4.12 \pm \\
0.50\end{array}$ & $\begin{array}{c}6.34 \pm \\
0.65\end{array}$ & $2.22 *$ & $0.77^{*}$ & $0.99 *$ \\
\hline Amino acids & $\begin{array}{c}20.50 \pm \\
1.90\end{array}$ & $\begin{array}{c}22.50 \pm \\
1.99\end{array}$ & $2.00^{\mathrm{NS}}$ & $\begin{array}{c}23.50 \pm \\
1.71\end{array}$ & $\begin{array}{c}25.65 \pm \\
2.00\end{array}$ & $2.15^{\mathrm{NS}}$ & $3.00^{*}$ & $3.15^{*}$ \\
\hline Fatty acids & $\begin{array}{c}2.50 \pm \\
0.10\end{array}$ & $\begin{array}{c}2.75 \pm \\
0.12\end{array}$ & $0.25 *$ & $\begin{array}{c}2.90 \pm \\
0.19\end{array}$ & $\begin{array}{c}3.50 \pm \\
0.20\end{array}$ & $0.60^{*}$ & $0.40^{*}$ & $0.75^{*}$ \\
\hline Moisture & $\begin{array}{c}76.40 \pm \\
3.24\end{array}$ & $\begin{array}{c}76.20 \pm \\
5.15\end{array}$ & $0.20^{\mathrm{NS}}$ & $\begin{array}{c}75.50 \pm \\
5.51\end{array}$ & $\begin{array}{c}75.00 \pm \\
4.95\end{array}$ & $0.50^{\mathrm{NS}}$ & $0.90^{\mathrm{NS}}$ & $1.20^{\mathrm{NS}}$ \\
\hline DNA & $\begin{array}{c}2.24 \pm \\
0.17\end{array}$ & $\begin{array}{c}2.30 \pm \\
1.91\end{array}$ & $0.06^{\mathrm{NS}}$ & $\begin{array}{c}2.25 \pm \\
0.10\end{array}$ & $\begin{array}{c}2.28 \pm \\
0.14\end{array}$ & $0.03^{\mathrm{NS}}$ & $0.01^{\mathrm{NS}}$ & $0.02^{\mathrm{NS}}$ \\
\hline RNA & $\begin{array}{c}4.00 \pm \\
0.22\end{array}$ & $\begin{array}{c}4.20 \pm \\
0.22\end{array}$ & $0.20^{\mathrm{NS}}$ & $\begin{array}{c}4.30 \pm \\
0.20\end{array}$ & $\begin{array}{c}4.80 \pm \\
0.36\end{array}$ & $0.50^{\mathrm{NS}}$ & $0.30 *$ & $0.60 *$ \\
\hline Ash & $\begin{array}{c}1.75 \pm \\
0.10\end{array}$ & $\begin{array}{c}1.80 \pm \\
0.10\end{array}$ & $0.05^{\mathrm{NS}}$ & $\begin{array}{c}1.70 \pm \\
0.10\end{array}$ & $\begin{array}{c}1.72 \pm \\
0.10\end{array}$ & $0.02^{\mathrm{NS}}$ & $0.05^{\mathrm{NS}}$ & $0.08^{\mathrm{NS}}$ \\
\hline
\end{tabular}

Each value is mean \pm SD of 3 individual observations. ${ }^{*}$ Significant at $10.0 \%$ level $(\mathrm{P}<0.1) .{ }^{\text {NS }}$ Not statistically significant. 
Table 3. Amino acids composition (g/ $100 \mathrm{~g}$ wet wt.) of muscle tissue of adult $M$. rosenbergii collected from two different natural culture sites

\begin{tabular}{|c|c|c|c|c|c|c|c|c|}
\hline \multirow[t]{2}{*}{ Amino Acids } & \multicolumn{3}{|c|}{ Male } & \multicolumn{3}{|c|}{ Female } & \multicolumn{2}{|c|}{$\begin{array}{c}\text { Difference } \\
\text { Between } \\
\text { Male and Female }\end{array}$} \\
\hline & Site-1 & Site-2 & Difference & Site-1 & Site-2 & Difference & Site-1 & Site-2 \\
\hline Phenylalanine & $\begin{array}{c}0.44 \pm \\
0.05 \\
\end{array}$ & $\begin{array}{c}0.55 \pm \\
0.05 \\
\end{array}$ & $0.11 *$ & $\begin{array}{c}0.64 \pm \\
0.06 \\
\end{array}$ & $\begin{array}{c}0.75 \pm \\
0.05 \\
\end{array}$ & $0.11 *$ & $0.20^{*}$ & $0.20 *$ \\
\hline Leucine & $\begin{array}{c}0.52 \pm \\
0.05\end{array}$ & $\begin{array}{c}0.60 \pm \\
0.05\end{array}$ & $0.08 *$ & $\begin{array}{c}0.64 \pm \\
0.05\end{array}$ & $\begin{array}{c}0.75 \pm \\
0.04\end{array}$ & $0.11^{*}$ & $0.12 *$ & $0.15^{*}$ \\
\hline $\begin{array}{l}\text { Tyrosine \& } \\
\text { Isoleucine }\end{array}$ & $\begin{array}{c}1.23 \pm \\
0.10 \\
\end{array}$ & $\begin{array}{c}1.30 \pm \\
0.15 \\
\end{array}$ & $0.07^{\mathrm{NS}}$ & $\begin{array}{c}1.42 \pm \\
0.10 \\
\end{array}$ & $\begin{array}{c}1.50 \pm \\
0.13 \\
\end{array}$ & $0.08^{\mathrm{NS}}$ & $0.19^{*}$ & $0.20 *$ \\
\hline Tryptophan & $\begin{array}{c}1.30 \pm \\
0.11 \\
\end{array}$ & $\begin{array}{c}1.40 \pm \\
0.15 \\
\end{array}$ & $0.10^{\mathrm{NS}}$ & $\begin{array}{c}1.55 \pm \\
0.15 \\
\end{array}$ & $\begin{array}{c}1.70 \pm \\
0.15 \\
\end{array}$ & $0.15^{\mathrm{NS}}$ & $0.25^{*}$ & $0.30 *$ \\
\hline Methionine & $\begin{array}{c}1.25 \pm \\
0.10 \\
\end{array}$ & $\begin{array}{c}1.34 \pm \\
0.14 \\
\end{array}$ & $0.06^{\mathrm{NS}}$ & $\begin{array}{c}1.40 \pm \\
0.10 \\
\end{array}$ & $\begin{array}{c}1.58 \pm \\
0.13 \\
\end{array}$ & $0.18^{*}$ & $0.15^{*}$ & $0.24 *$ \\
\hline Valine & $\begin{array}{c}0.50 \pm \\
0.05 \\
\end{array}$ & $\begin{array}{c}0.60 \pm \\
0.08 \\
\end{array}$ & $0.10^{*}$ & $\begin{array}{c}0.74 \pm \\
0.05 \\
\end{array}$ & $\begin{array}{c}0.82 \pm \\
0.06 \\
\end{array}$ & $0.08^{*}$ & $0.24 *$ & $0.22 *$ \\
\hline Alanine & $\begin{array}{c}0.45 \pm \\
0.04 \\
\end{array}$ & $\begin{array}{c}0.74 \pm \\
0.05 \\
\end{array}$ & $0.29 *$ & $\begin{array}{c}0.50 \pm \\
0.04 \\
\end{array}$ & $\begin{array}{c}0.80 \pm \\
0.05 \\
\end{array}$ & $0.30 *$ & $0.05^{*}$ & $0.10 *$ \\
\hline Threonine & $\begin{array}{c}0.40 \pm \\
0.04 \\
\end{array}$ & $\begin{array}{c}0.44 \pm \\
0.04 \\
\end{array}$ & $0.04^{\mathrm{NS}}$ & $\begin{array}{c}0.58 \pm \\
0.05 \\
\end{array}$ & $\begin{array}{c}0.70 \pm \\
0.06 \\
\end{array}$ & $0.12 *$ & $0.18^{*}$ & $0.26^{*}$ \\
\hline Cysteine & $\begin{array}{c}0.55 \pm \\
0.07 \\
\end{array}$ & $\begin{array}{c}0.65 \pm \\
0.05 \\
\end{array}$ & $0.10^{*}$ & $\begin{array}{c}0.60 \pm \\
0.05 \\
\end{array}$ & $\begin{array}{c}0.72 \pm \\
0.05 \\
\end{array}$ & $0.12 *$ & $0.04^{\mathrm{NS}}$ & $0.07 *$ \\
\hline Proline & $\begin{array}{c}0.52 \pm \\
0.06\end{array}$ & $\begin{array}{c}0.70 \pm \\
0.06\end{array}$ & $0.17 *$ & $\begin{array}{c}0.64 \pm \\
0.05\end{array}$ & $\begin{array}{c}0.86 \pm \\
0.07\end{array}$ & $0.22 *$ & $0.12 *$ & $0.16^{*}$ \\
\hline Glutamic acid & $\begin{array}{c}0.48 \pm \\
0.06 \\
\end{array}$ & $\begin{array}{c}0.60 \pm \\
0.05 \\
\end{array}$ & $0.12^{*}$ & $\begin{array}{c}0.56 \pm \\
0.04 \\
\end{array}$ & $\begin{array}{c}0.70 \pm \\
0.05 \\
\end{array}$ & $0.14^{\mathrm{NS}}$ & $0.08^{*}$ & $0.10^{*}$ \\
\hline Argenine & $\begin{array}{c}0.52 \pm \\
0.05 \\
\end{array}$ & $\begin{array}{c}0.60 \pm \\
0.06 \\
\end{array}$ & $0.08^{*}$ & $\begin{array}{c}0.65 \pm \\
0.05 \\
\end{array}$ & $\begin{array}{c}0.75 \pm \\
0.05 \\
\end{array}$ & $0.10^{*}$ & $0.13^{*}$ & $0.15^{*}$ \\
\hline Serine & $\begin{array}{c}1.25 \pm \\
0.14 \\
\end{array}$ & $\begin{array}{c}1.35 \pm \\
0.14 \\
\end{array}$ & $0.10^{\mathrm{NS}}$ & $\begin{array}{c}1.40 \pm \\
0.17 \\
\end{array}$ & $\begin{array}{c}1.72 \pm \\
0.16 \\
\end{array}$ & $0.32 *$ & $0.15^{\mathrm{NS}}$ & $0.38 *$ \\
\hline Aspartic acid & $\begin{array}{c}0.50 \pm \\
0.05 \\
\end{array}$ & $\begin{array}{c}0.56 \pm \\
0.05 \\
\end{array}$ & $0.06^{\mathrm{NS}}$ & $\begin{array}{c}0.64 \pm \\
0.05 \\
\end{array}$ & $\begin{array}{c}0.80 \pm \\
0.06 \\
\end{array}$ & $0.16^{*}$ & $0.14^{*}$ & $0.24 *$ \\
\hline Histidine & $\begin{array}{c}1.48 \pm \\
0.16 \\
\end{array}$ & $\begin{array}{c}1.50 \pm \\
0.16 \\
\end{array}$ & $0.02^{\mathrm{NS}}$ & $\begin{array}{c}1.75 \pm \\
0.13 \\
\end{array}$ & $\begin{array}{c}1.90 \pm \\
0.15 \\
\end{array}$ & $0.15^{\mathrm{NS}}$ & $0.27^{*}$ & $0.40 *$ \\
\hline Glutamine & $\begin{array}{c}0.30 \pm \\
0.05\end{array}$ & $\begin{array}{c}0.32 \pm \\
0.05\end{array}$ & $0.02^{\mathrm{NS}}$ & $\begin{array}{c}0.34 \pm \\
0.04\end{array}$ & $\begin{array}{c}0.40 \pm \\
0.04\end{array}$ & $0.06^{*}$ & $0.04^{\mathrm{NS}}$ & $0.08 *$ \\
\hline Lycine & $\begin{array}{c}0.44 \pm \\
0.05 \\
\end{array}$ & $\begin{array}{c}0.50 \pm \\
0.05 \\
\end{array}$ & $0.06^{\mathrm{NS}}$ & $\begin{array}{c}0.62 \pm \\
0.05 \\
\end{array}$ & $\begin{array}{c}0.75 \pm \\
0.05 \\
\end{array}$ & $0.13 *$ & $0.18^{*}$ & $0.25^{*}$ \\
\hline Glycine & $\begin{array}{c}0.53 \pm \\
0.06\end{array}$ & $\begin{array}{c}0.60 \pm \\
0.06\end{array}$ & $0.17 *$ & $\begin{array}{c}0.56 \pm \\
0.05\end{array}$ & $\begin{array}{c}0.80 \pm \\
0.06\end{array}$ & $0.24 *$ & $0.03^{\mathrm{NS}}$ & $0.20 *$ \\
\hline
\end{tabular}

Amino acids in bold letters represent indispensable amino acids.

Each value is mean $\pm \mathrm{SD}$ of 3 individual observations. *Significant at $10.0 \%$ level $(\mathrm{P}<0.1)$. ${ }^{\text {NS }}$ Not statistically significant. 
Table 4. Fatty acids composition (mg/ $100 \mathrm{~g}$ wet wt.) of muscle tissue of adult $M$. rosenbergii collected from two different natural culture sites

\begin{tabular}{|c|c|c|c|c|c|c|c|c|}
\hline \multirow[t]{2}{*}{ Fatty Acids Profile } & \multicolumn{3}{|c|}{ Male } & \multicolumn{3}{|c|}{ Female } & \multicolumn{2}{|c|}{$\begin{array}{c}\text { Difference } \\
\text { Between } \\
\text { Male and Female }\end{array}$} \\
\hline & Site-1 & Site-2 & Difference & Site-1 & Site-2 & Difference & Site-1 & Site-2 \\
\hline Myristic acid (14:0) & $\begin{array}{c}45.5+ \\
1.1\end{array}$ & $\begin{array}{c}46.0+ \\
1.5\end{array}$ & $0.50^{\mathrm{NS}}$ & $\begin{array}{c}51.5+ \\
1.5\end{array}$ & $\begin{array}{c}52.0+ \\
2.0\end{array}$ & $0.50^{\mathrm{NS}}$ & $6.00^{*}$ & $7.00 *$ \\
\hline Palmitic acid (16:0) & $\begin{array}{c}435.0+ \\
12.5\end{array}$ & $\begin{array}{c}438.0+ \\
15.0\end{array}$ & $3.00^{\mathrm{NS}}$ & $\begin{array}{c}450.0+ \\
12.5\end{array}$ & $\begin{array}{c}454.2+ \\
12.0\end{array}$ & $4.20^{\mathrm{NS}}$ & $15.00^{\mathrm{NS}}$ & $15.80^{\mathrm{NS}}$ \\
\hline Palmitoleic acid (16:1) & $\begin{array}{c}50.2+ \\
1.2\end{array}$ & $\begin{array}{c}50.8+ \\
1.2\end{array}$ & $0.60^{\mathrm{NS}}$ & $\begin{array}{c}55.5+ \\
1.5\end{array}$ & $\begin{array}{c}56.2+ \\
1.5\end{array}$ & $0.70^{\mathrm{NS}}$ & $4.30^{*}$ & $6.60 *$ \\
\hline Stearic acid (18:0) & $\begin{array}{c}230.0+ \\
10.5\end{array}$ & $\begin{array}{c}232.5+ \\
12.5\end{array}$ & $2.50^{\mathrm{NS}}$ & $\begin{array}{c}240.5+ \\
15.0\end{array}$ & $\begin{array}{c}242.4+ \\
17.0\end{array}$ & $1.90^{\mathrm{NS}}$ & $10.50^{\mathrm{NS}}$ & $10.10^{\mathrm{NS}}$ \\
\hline Oleic acid (16:1) & $\begin{array}{c}435.0+ \\
12.0\end{array}$ & $\begin{array}{c}442.0+ \\
10.5\end{array}$ & $7.00^{\mathrm{NS}}$ & $\begin{array}{c}450.4+ \\
12.0\end{array}$ & $\begin{array}{c}456.5+ \\
10.5\end{array}$ & $6.10^{\mathrm{NS}}$ & $15.40 *$ & $14.50^{*}$ \\
\hline Linoleic acid (18:2) & $\begin{array}{c}370.0+ \\
10.0\end{array}$ & $\begin{array}{c}373.2+ \\
10.5\end{array}$ & $3.20^{\mathrm{NS}}$ & $\begin{array}{c}385.5+ \\
10.0\end{array}$ & $\begin{array}{c}390.2+ \\
12.0\end{array}$ & $4.70^{\mathrm{NS}}$ & $15.50^{*}$ & $17.00 *$ \\
\hline Linolenic acid (18:3) & $\begin{array}{c}48.2+ \\
1.5\end{array}$ & $\begin{array}{c}50.7+ \\
1.2\end{array}$ & $2.50 *$ & $\begin{array}{c}51.2+ \\
1.5\end{array}$ & $\begin{array}{c}54.5+ \\
1.8\end{array}$ & $3.30^{*}$ & $3.00 *$ & $3.80^{*}$ \\
\hline $\begin{array}{c}\text { Eicosapentaenoic acid } \\
\qquad(20: 5)\end{array}$ & $\begin{array}{c}140.2+ \\
5.0\end{array}$ & $\begin{array}{c}149.8+ \\
5.0\end{array}$ & $9.60^{*}$ & $\begin{array}{c}150.0+ \\
5.0\end{array}$ & $\begin{array}{c}158.8+ \\
5.0\end{array}$ & $8.60 *$ & $10.80^{*}$ & $11.00 *$ \\
\hline $\begin{array}{c}\text { Decosahexanoic acid } \\
\qquad(22: 5)\end{array}$ & $\begin{array}{c}43.6+ \\
1.2\end{array}$ & $\begin{array}{c}45.7+ \\
1.5\end{array}$ & $2.10^{*}$ & $\begin{array}{c}46.0+ \\
1.2\end{array}$ & $\begin{array}{c}48.6+ \\
1.5\end{array}$ & $2.60 *$ & $2.40^{*}$ & $2.90^{*}$ \\
\hline $\begin{array}{c}\text { Octadecatatrienoic acid } \\
\qquad(18: 4)\end{array}$ & $\begin{array}{c}30.0+ \\
1.5\end{array}$ & $\begin{array}{c}34.0+ \\
1.0\end{array}$ & $4.00^{*}$ & $\begin{array}{c}35.0+ \\
1.0\end{array}$ & $\begin{array}{c}40.5+ \\
1.5\end{array}$ & $5.50 *$ & $5.00^{*}$ & $6.50^{*}$ \\
\hline Arachidic acid (20:0) & $\begin{array}{c}50.5+ \\
1.5\end{array}$ & $\begin{array}{c}52.0+ \\
1.4\end{array}$ & $1.50^{\mathrm{NS}}$ & $\begin{array}{c}55.3+ \\
1.5\end{array}$ & $\begin{array}{c}56.8+ \\
1.5\end{array}$ & $1.60^{\mathrm{NS}}$ & $4.60^{*}$ & $4.80^{*}$ \\
\hline Docosanic acid (22:1) & $\begin{array}{c}60.4+ \\
1.7\end{array}$ & $\begin{array}{c}64.5+ \\
1.5\end{array}$ & $4.10^{*}$ & $\begin{array}{c}70.6+ \\
1.7\end{array}$ & $\begin{array}{c}71.9+ \\
2.0\end{array}$ & $1.30^{\mathrm{NS}}$ & $10.20^{*}$ & $7.40^{*}$ \\
\hline Erucic acid (22:1) & $\begin{array}{c}40.0+ \\
1.5\end{array}$ & $\begin{array}{c}41.8+ \\
1.2\end{array}$ & $1.80^{*}$ & $\begin{array}{c}45.5+ \\
1.5\end{array}$ & $\begin{array}{c}50.4+ \\
1.2\end{array}$ & $4.90^{*}$ & $5.50^{*}$ & $8.60^{*}$ \\
\hline Lignoceric acid (24:0) & $\begin{array}{c}61.0+ \\
2.0\end{array}$ & $\begin{array}{c}63.8+ \\
2.0\end{array}$ & $2.80 *$ & $\begin{array}{c}64.0+ \\
2.0\end{array}$ & $\begin{array}{c}65.8+ \\
2.0\end{array}$ & $1.80^{\mathrm{NS}}$ & $3.00^{*}$ & $2.00^{\mathrm{NS}}$ \\
\hline Arachidonic acid (20:4) & $\begin{array}{c}22.0+ \\
1.0\end{array}$ & $\begin{array}{c}25.2+ \\
1.2\end{array}$ & $3.20 *$ & $\begin{array}{c}26.8+ \\
1.5\end{array}$ & $\begin{array}{c}28.2+ \\
1.5\end{array}$ & $1.40^{\mathrm{NS}}$ & $4.80^{*}$ & $3.00 *$ \\
\hline
\end{tabular}

Fatty acids in bold letters represent unsaturated fatty acids.

Each value is mean $\pm \mathrm{SD}$ of 3 individual observations. ${ }^{*}$ Significant at $10.0 \%$ level $(\mathrm{P}<0.1)$. ${ }^{\text {NS }}$ Not statistically significant. 